\title{
Analysis of nutritional status of children aged 10-13 in selected areas of the Silesian Province of Poland and assessment of their parents' knowledge on child nutrition guidelines
}

\author{
Analiza stopnia odżywienia dzieci w wieku 10-13 lat na wybranych terenach województwa śląskiego \\ (Polska) wraz z oceną wiedzy rodziców na temat zasad racjonalnego odżywiania ich dzieci
}

\author{
${ }^{1}$ Department of Descriptive and Topographic Anatomy, Faculty of Medical Sciences in Zabrze, Medical University of Silesia in Katowice, Zabrze, Poland \\ ${ }^{2}$ Department of Medical and Molecular Biology, Faculty of Medical Sciences in Zabrze, Medical University of Silesia in Katowice, Zabrze, Poland \\ Correspondence: Paweł Jonczyk, Department of Descriptive and Topographic Anatomy, Faculty of Medical Sciences in Zabrze, Medical University of Silesia in Katowice, Jordana 19, 41-808 Zabrze, Poland, \\ e-mail: pawel_jonczyk@02.pl
}

\begin{abstract}
Aim of the study: In this study, we analysed the nutritional status of children aged 10-13 years living in selected areas of the Silesian Province of Poland and assessed their parents' knowledge of dietary guidelines. Materials and methods: The study was conducted in a group of parents of children aged 10-13 years in selected primary schools in the Silesian Province, Poland. Approximately 1,000 paper copies of an originally developed questionnaire were distributed among the respondents. The survey included questions about children's anthropometric measurements, family structure and parents' knowledge of guidelines regarding their children's nutrition and physical activity. Statistical analysis was performed on 589 questionnaires. Results: The problem of obesity was present in $26.35 \%$ of children, while $16.44 \%$ were found to be overweight. In the study group, $21.84 \%$ of children were undernourished. Approximately half of parents know that a balanced child diet should consist of at least five meals a day. Only $7 \%$ of parents are aware of the appropriate level of milk and dairy product consumption by children, less than $9 \%$ of daily fruit and vegetable consumption and more than $51 \%$ of the combined consumption of meat, fish and eggs. On average, one in three parents do not know what the recommended share of the basic nutrients in the daily energy intake of a child is. More than half of the surveyed parents do not know the calorific value of fat, carbohydrates, protein, ethyl alcohol and fibre. Over $43.4 \%$ of the respondents know that a child should have 30-60 minutes of moderate physical activity daily. Conclusions: The knowledge of basic guidelines regarding nutrition and physical activity of children aged 10-13 years from selected areas of the Silesian Province among their parents is insufficient. Parents do not have the necessary knowledge regarding the recommended quantity and quality of food eaten by their children. It is necessary to implement educational programmes in primary schools addressed to both pupils and their parents.
\end{abstract}

Keywords: nutritional status disorders in children, overweight, obesity, parental knowledge, nutrition guidelines

Streszczenie Cel: W niniejszym opracowaniu dokonano analizy stopnia odżywienia dzieci w wieku 10-13 lat mieszkających na wybranych terenach województwa śląskiego (Polska) wraz z oceną wiedzy ich rodziców na temat zasad racjonalnego odżywiania. Materiał i metoda: Badania przeprowadzono w grupie rodziców dzieci w wieku 10-13 lat w wybranych szkołach podstawowych w województwie śląskim. Respondentom rozdano około 1000 autorskich kwestionariuszy w wersji papierowej, zawierających pytania dotyczące danych antropometrycznych dzieci, struktury rodziny oraz zagadnień związanych z wiedzą rodziców na temat odżywiania ich dzieci i ich aktywności fizycznej. Do analizy statystycznej zakwalifikowano 589 kwestionariuszy ankiet. Wyniki: Problem otyłości dotyczył 26,35\% badanych dzieci, z kolei nadwagą dotkniętych było $16,44 \%$ analizowanej populacji. Stan niedożywienia w badanej grupie dzieci stwierdzono u 21,84\% respondentów. Mniej więcej połowa rodziców wie, że zbilansowana dieta dziecka powinna się składać z co najmniej pięciu posiłków na dobę. Jedynie 7\% rodziców ma świadomość, jakie jest prawidłowe spożycie mleka i jego przetworów przez dzieci, niespełna 9\% dzienne spożycie warzyw i owoców, ponad 51\% - spożycie produktów z grupy mięso-ryby-jaja. Średnio co trzeci rodzic nie wie, jaki jest zalecany udział podstawowych składników odżywczych w dziennym pokryciu zapotrzebowania na energię w diecie dziecka. Ponad połowa ankietowanych rodziców nie orientuje się, jaka jest kaloryczność tłuszczów, węglowodanów, białek, alkoholu etylowego oraz błonnika. Ponad 43,4\% respondentów wie, że umiarkowana aktywność fizyczna powinna 


\title{
Analysis of nutritional status of children aged 10-13 in selected areas of the Silesian Province of Poland and assessment of their parents' knowledge on child nutrition guidelines
}

\begin{abstract}
zajmować dziecku dziennie 30-60 minut. Wnioski: Znajomość podstawowych zasad dotyczących racjonalnego odżywiania i aktywności fizycznej dzieci w wieku 10-13 lat z wybranych terenów województwa śląskiego wśród ich rodziców jest niedostateczna. Rodzice nie mają stosownej wiedzy dotyczącej zalecanych ilości i jakości żywności spożywanej przez ich dzieci. Niezbędne jest wprowadzenie w szkołach podstawowych programów edukacyjnych skierowanych zarówno do uczniów, jak i do ich rodziców.
\end{abstract}

Słowa kluczowe: zaburzenia stopnia odżywienia dzieci, nadwaga, otyłość, wiedza rodziców, racjonalne odżywianie

\section{INTRODUCTION}

S ince 1997, the World Health Organization has considered obesity to be the most important public health problem. It is estimated that there are currently more than billion overweight individuals in the world, while 300 million people are affected by obesity ${ }^{(1)}$. According to an International Obesity Task Force (IOTF) study, 155 million children are overnourished, with 30-45 million of them being obese. Epidemiological data from different countries differ; however, an alarming trend of increasing prevalence of nutrition disorders in the population of children and adults has been observed ${ }^{(2)}$. An audit conducted by Poland's Supreme Audit Office in Polish schools in 2015-2016 revealed that the proportion of pupils with abnormal body weight, i.e. with overweight and underweight was as high as $22 \%$, which meant that one in five pupils was affected in the schools included in the study ${ }^{(3)}$. The main causes of overweight and obesity include poor nutrition in terms of quality and quantity, and a lack of appropriate physical activity. These factors lead to the so-called primary obesity ( $60-70 \%$ of obese individuals). Genetic factors are responsible for only $30-40 \%$ of obesity cases ${ }^{(4)}$.

Abnormal, excessive body weight in relation to age and height, i.e. overweight and obesity, are associated with numerous complications. These include health problems related to abnormal further growth and development of a young body, and late consequences in adulthood (the most common sequelae of obesity are presented in Tab. 1). For this reason, parental knowledge of nutrition guidelines seems to have such a high significance for the development of appropriate eating habits in children. Parental awareness regarding proper child nutrition should include:

- knowledge of dietary guidelines for different phases of child development;

- knowledge of the child's needs, temperament and the current developmental phase;

- knowledge of the possible dangers associated with poor nutrition (overweight, obesity, undernutrition, anorexia, bulimia, diabetes).

Research shows that even those parents who only have a basic knowledge of nutrition and healthy lifestyle guidelines usually appreciate the huge importance of child nutrition and know that it is subject to change due to various factors ${ }^{(6,7)}$. In this study, we analysed the nutritional status of children aged 10-13 years living in selected areas of the Silesian Province of Poland and assessed parental knowledge of dietary guidelines.

\section{MATERIALS AND METHODS}

The study was conducted in 2018-2019 in a group of parents of children aged 10-13 years in selected primary schools of the Silesian Province of Poland upon the approval of the schools' headmasters. Approximately 1,000 paper copies of an originally developed questionnaire were distributed among the respondents. The survey included 40 questions with one or more answers to be selected depending on the type of question. The questions mainly concerned children's

\begin{tabular}{|c|c|}
\hline Early complications & Complications in adulthood \\
\hline $\begin{array}{l}\text { - Hypertension } \\
\text { - Type } 2 \text { diabetes } \\
\text { - Insulin resistance } \\
\text { - Dyslipidaemia } \\
\text { - Non-alcoholic fatty liver disease } \\
\text { - Metabolic syndrome } \\
\text { - Hypertransaminasemia } \\
\text { - Cholecystolithiasis } \\
\text { - Glomerulosclerosis } \\
\text { - Bronchial asthma } \\
\text { - Obstructive sleep apnoea } \\
\text { - Bone and joint disorders* } \\
\text { - Emotional problems (low self-esteem) } \\
\text { - Early puberty } \\
\text { - Hyperandrogenism, polycystic ovary syndrome }\end{array}$ & $\begin{array}{l}\text { - Adult obesity } \\
\text { - Cardiovascular risk factors** } \\
\text { - Left ventricular hypertrophy } \\
\text { - Reduced life expectancy } \\
\text { - Hormonal imbalances leading to male and female infertility } \\
\text { - Depression, emotional problems and anxiety disorders } \\
\text { - Increased risk of cancer, e.g. breast, ovarian and endometrial cancer }\end{array}$ \\
\hline
\end{tabular}

Tab. 1. Consequences of overweight and obesity in childhood and adulthood ${ }^{(2,4,5)}$ 


\begin{tabular}{|c|c|c|}
\hline Age group & Boys & Girls \\
\hline 10 & 116 & 116 \\
\hline 11 & 57 & 83 \\
\hline 12 & 76 & 70 \\
\hline 13 & 36 & 35 \\
\hline Total & 285 & 304 \\
\hline
\end{tabular}

Tab. 2. Numbers of children in the study population

anthropometric measurements, family structure, economic conditions, dietary habits, physical activity of children and parents, and parental knowledge of guidelines regarding nutrition and physical activity of children. Parents performed anthropometric measurements at home after receiving basic instruction during parent-teacher conferences. Statistical analysis was performed on 589 questionnaires. Questionnaires completed in a way that was not compliant with the instructions were rejected. There were 304 girls (51.61\%) and 285 boys ( $48.39 \%$ ) among the children included in the study. Details regarding study group quantity are presented in Tab. 2. This research project aimed to determine the current nutritional status of the study population of children based on their body mass index (BMI) values in relation to the centile standards established in the OLAF multicentre study conducted in 2007-2009 in Poland ${ }^{(8)}$. The present study also assessed parental knowledge of child nutrition guidelines. The IBM SPSS Statistics package, version 25, was used for statistical analysis in order to find answers to research questions and to verify study hypotheses. Descriptive statistics were calculated and numerous frequency analyses were conducted. Comparative analyses were also performed using the parametric Student's $t$-test for independent samples and non-parametric tests: Mann-Whitney $U$ and Kruskal-Wallis tests, and correlation analyses were conducted with Pearson's $r$ and Spearman's rho coefficients. Results with $p=0.05$ were considered statistically significant in the present study.

\section{RESULTS}

\section{Demographic data}

Slightly over $88 \%$ of the subjects came from two-parent families, $11.66 \%$ came from single-parent families, while two children lived with foster families. The largest proportion of the surveyed parents $(58.57 \%)$ had two children, $19.02 \%$ had one child and $22.41 \%$ had three or more children. The mean age of mothers taking part in the survey was $39.22 \pm 4.78$ years (with the lowest and highest age being 28 and 55 years, respectively), while the mean age of fathers was $41.66 \pm 5.53$ years (with the lowest and highest age being 27 and 65 years, respectively). The parents' level of education was diverse. There were $39.39 \%$ of women and $40.10 \%$ of men with secondary education. Among women, higher education was most common (42.26\%), while most men had secondary education. Among the subjects, $53.18 \%$ lived in cities, $17.38 \%$ lived in rural areas and $29.44 \%$ lived

\begin{tabular}{|c|c|c|c|c|}
\hline \multirow{2}{*}{$\begin{array}{c}\text { Age } \\
\text { group }\end{array}$} & \multicolumn{4}{|c|}{ Nutritional status } \\
\cline { 2 - 5 } & Obesity & Overweight & $\begin{array}{c}\text { Normal body } \\
\text { weight }\end{array}$ & Undernutrition \\
\hline 10 & $25.43 \%$ & $13.79 \%$ & $49.57 \%$ & $11.21 \%$ \\
\hline 11 & $29.29 \%$ & $21.43 \%$ & $32.86 \%$ & $16.42 \%$ \\
\hline 12 & $25.34 \%$ & $16.44 \%$ & $29.45 \%$ & $28.77 \%$ \\
\hline 13 & $25.35 \%$ & $14.08 \%$ & $29.58 \%$ & $30.99 \%$ \\
\hline Mean & $\mathbf{2 6 . 3 5 \%}$ & $\mathbf{1 6 . 4 4} \%$ & $\mathbf{3 5 . 3 7 \%}$ & $\mathbf{2 1 . 8 5} \%$ \\
\hline
\end{tabular}

Tab. 3. Nutritional status figures in the study population of children

in small towns. As for body weight, $78.3 \%$ of parents had a normal body mass, while $21.7 \%$ of them were overweight or obese.

\section{Analysis of children's nutritional status}

Based on anthropometric measurements and calculated BMI, the children's nutritional status was determined with regard to the European standards. It was assumed that underweight children were those whose BMI was below the $5^{\text {th }}$ centile for a given population with regard to age and sex, overweight children were those with a BMI between the $85^{\text {th }}$ and $95^{\text {th }}$ centile and obese children had a BMI above the $95^{\text {th }}$ centile. The problem of obesity affected $26.35 \%$ of children in the study population, while $16.44 \%$ of them were found to be overweight. It turned out that in the study group, $21.84 \%$ of children were undernourished. A normal body mass in relation to height and sex was present in $35.37 \%$ of the subjects. Nutritional status figures are shown in Tab. 3.

\section{Analysis of parental knowledge on guidelines regarding healthy eating and physical activity of children}

This part of the paper presents findings concerning parental knowledge of healthy eating guidelines for children. Nearly half of parents (47.4\%) were correct to indicate that a proper, balanced child diet should consist of at least five meals a day. There were $40.4 \%$ of parents who thought that the diet should include three meals and an afternoon snack. Other respondents believed that a proper, balanced child diet should include three meals (6.3\% of the subjects) or two large meals ( $1.7 \%$ of the subjects). There were $1.5 \%$ of parents who admitted to not knowing the answer to this question, while $2.7 \%$ of the subjects did not provide any answer at all. The results are presented in Tab. 4.

Another question concerned the consumption of milk or dairy products (e.g. yoghurt, buttermilk, cheese) by children. It turned out that $42.5 \%$ of parents were wrong to believe that the daily consumption of milk or dairy products by a child should include one serving. On average, one in four respondents (26.8\%) thought that a child should consume two servings of milk or dairy products every day. The opinion that children do not need to consume dairy every day was shared by $11.0 \%$ of the respondents. Only $7.0 \%$ 


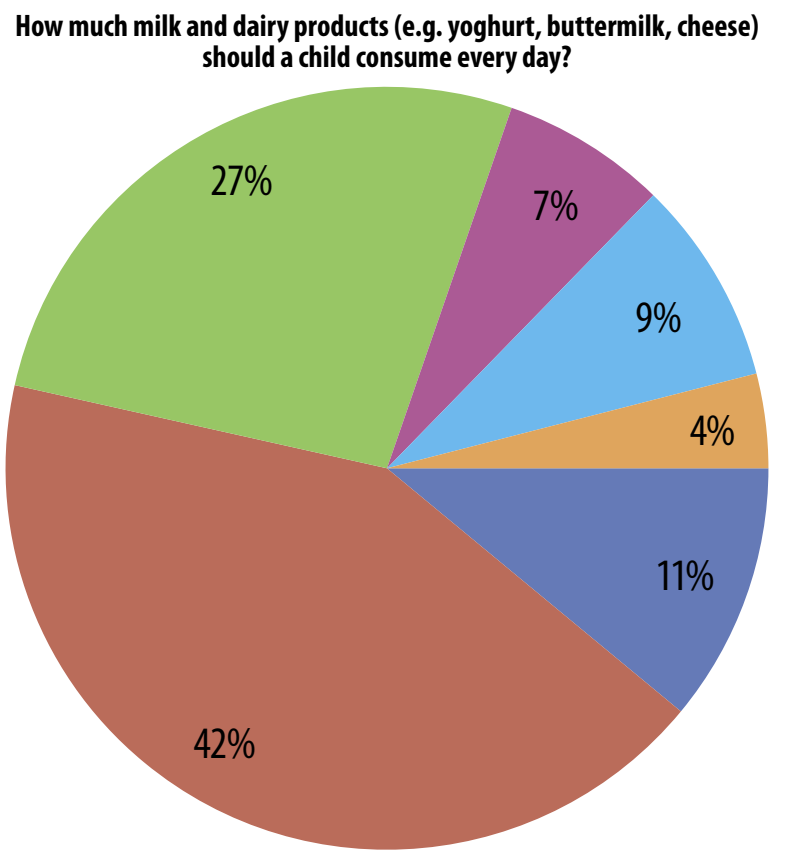

A child does not need to eat dairy every day

One serving

Two servings

At least three or four servings

I do not know

No answer

Fig. 1. Percentages of individuals providing a given answer to the question: "How much milk and dairy products (e.g. yoghurt, buttermilk, cheese) should a child consume every day?"

of the subjects were correct to indicate that there should be three to four servings of milk or dairy products a day in a child's diet. There were $8.7 \%$ of parents who admitted to having no knowledge on the subject, while $4.0 \%$ did not provide any answer to this question at all. The results are illustrated in Fig. 1.

A decisive majority of parents were incorrect to believe that children should eat one (40.1\%) or two to three (38.4\%) servings of fruit and vegetables daily. Only $8.8 \%$ of the subjects indicated correctly that the daily intake of fruit and vegetables by children should include at least five servings. The rest of the respondents believed that a proper children's diet should consist of four servings of fruit and vegetables

\begin{tabular}{|c|c|c|}
\hline Answer selected & $\boldsymbol{n}$ & $\%$ \\
\hline Two large meals & 11 & 1.7 \\
\hline Three meals & 41 & 6.3 \\
\hline $\begin{array}{c}\text { Three meals and } \\
\text { an afternoon snack }\end{array}$ & 265 & 40.4 \\
\hline Five meals or more & 311 & 47.4 \\
\hline I do not know & 10 & 1.5 \\
\hline No answer & 18 & 2.7 \\
\hline
\end{tabular}

Tab. 4. Numbers and percentages of individuals providing a given answer to the question: "How many meals a day should a child's proper, balanced diet include?"

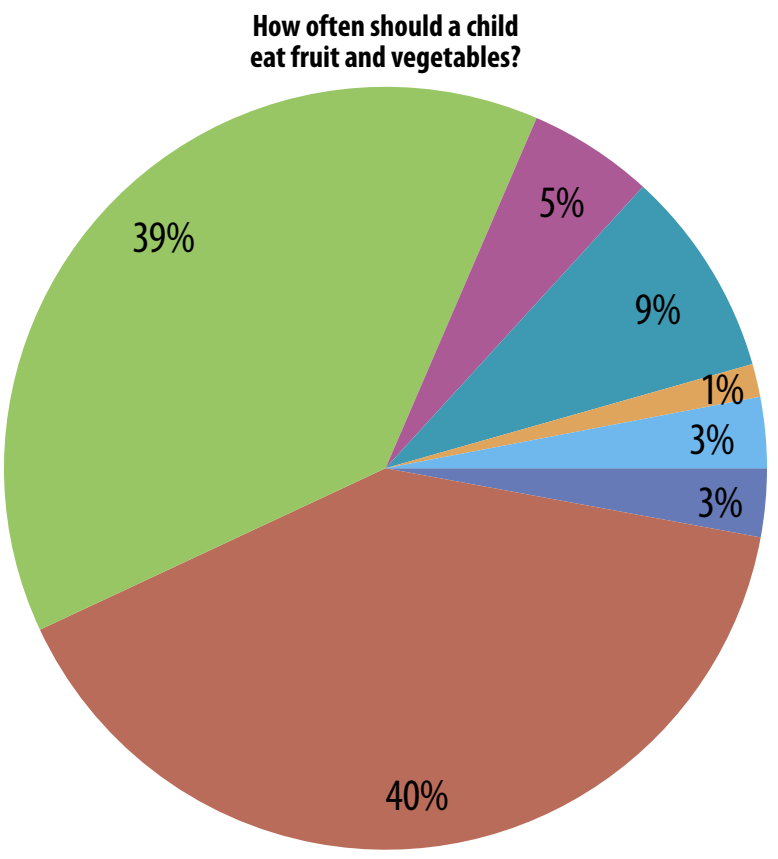

Every other day

One serving every day

Two to three servings every day

Four servings every day

At least five servings a day

I do not know

No answer

Fig. 2. Percentages of individuals providing a given answer to the question: "How often should a child eat fruit and vegetables?"

a day (5.3\% of the subjects) or that such products should be eaten every other day (2.9\%). There were $1.4 \%$ of the respondents who admitted to not knowing the answer to the question, while 3.0\% did not provide any answer at all. The results are presented in a diagram in Fig. 2.

Another issue raised in the questionnaire was combined daily consumption of meat, fish and eggs by children. More than half of the respondents (51.4\%) were right to indicate that children should consume one serving of meat, fish or eggs a day. Nearly one in five parents (18.1\%) believed that children do not need to consume these products every day. The remaining respondents were convinced that children should eat two ( $15.2 \%$ of the subjects) or three to four (4.3\%) servings of products from the meat, fish and eggs group daily. There were $7.6 \%$ of the subjects who did not know how many servings of such products a child should consume every day, while $3.4 \%$ of parents did not respond to this question. The results are presented in Fig. 3.

Further questions were about the knowledge of parents on the recommended percentage of carbohydrates, protein and fat to cover the daily energy demand of a child. The results are presented in Fig. 4-6. On average, one in three parents (from $31.6 \%$ to $35.8 \%$ ) admitted to having no knowledge of the recommended proportion of the basic nutrients in the daily energy intake of a child. A correct answer regarding 


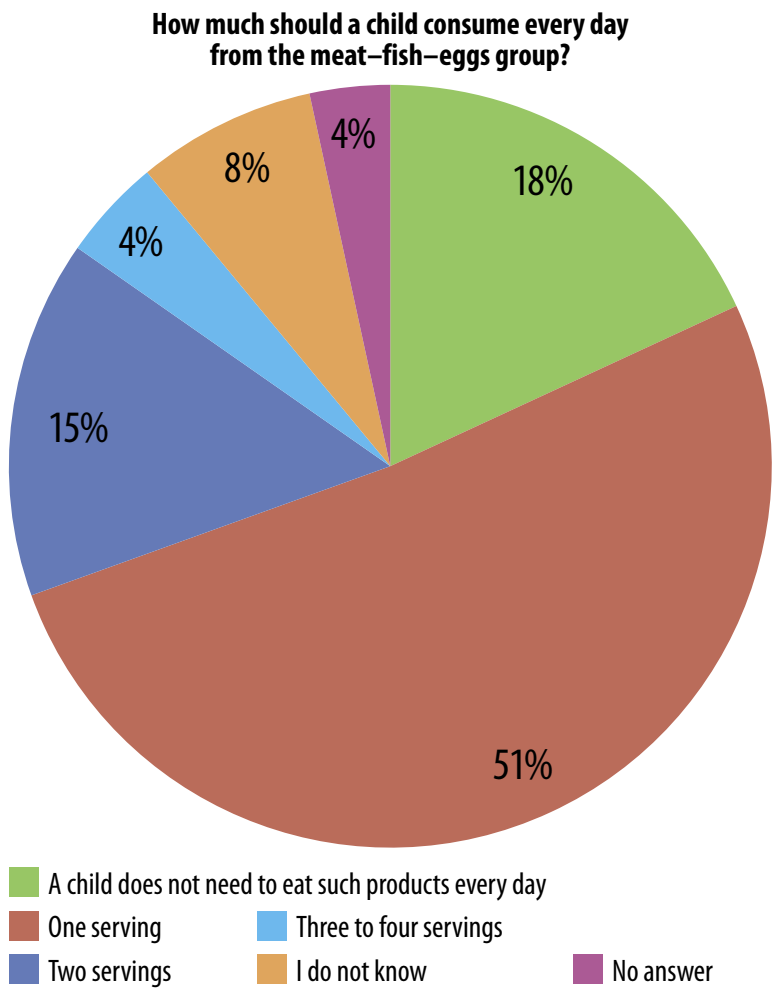

Fig. 3. Percentages of individuals providing a given answer to the question: "How much should a child consume every day from the meat-fish-eggs group?"

\section{What is the recommended share of carbohydrates in the daily energy intake of a child?}

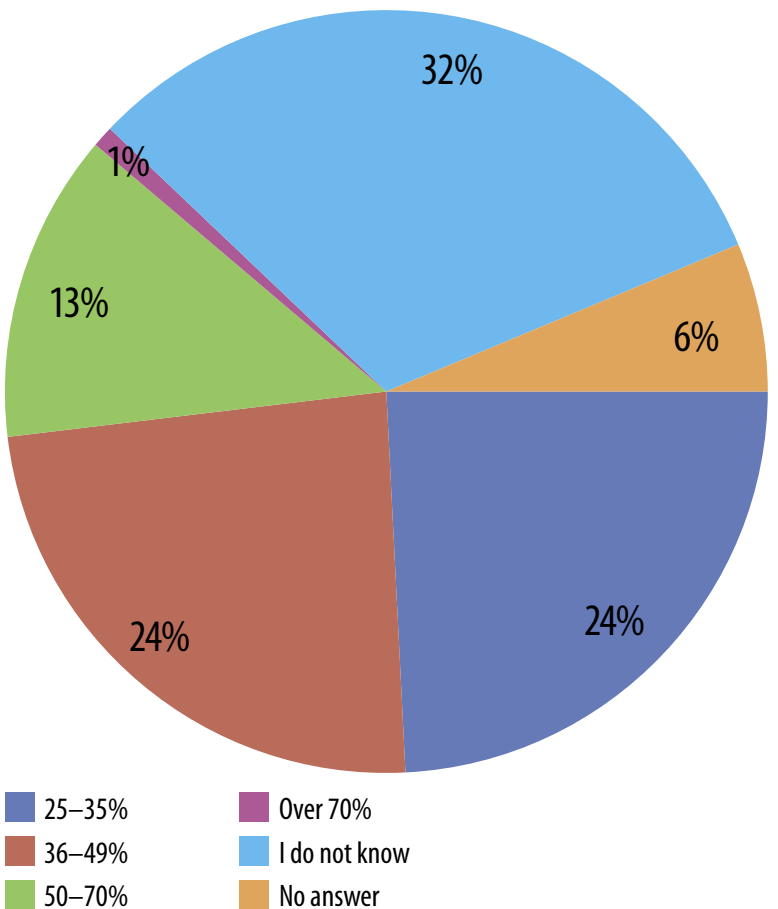

Fig. 4. Percentages of individuals providing a given answer to the question: "What is the recommended share of carbohydrates

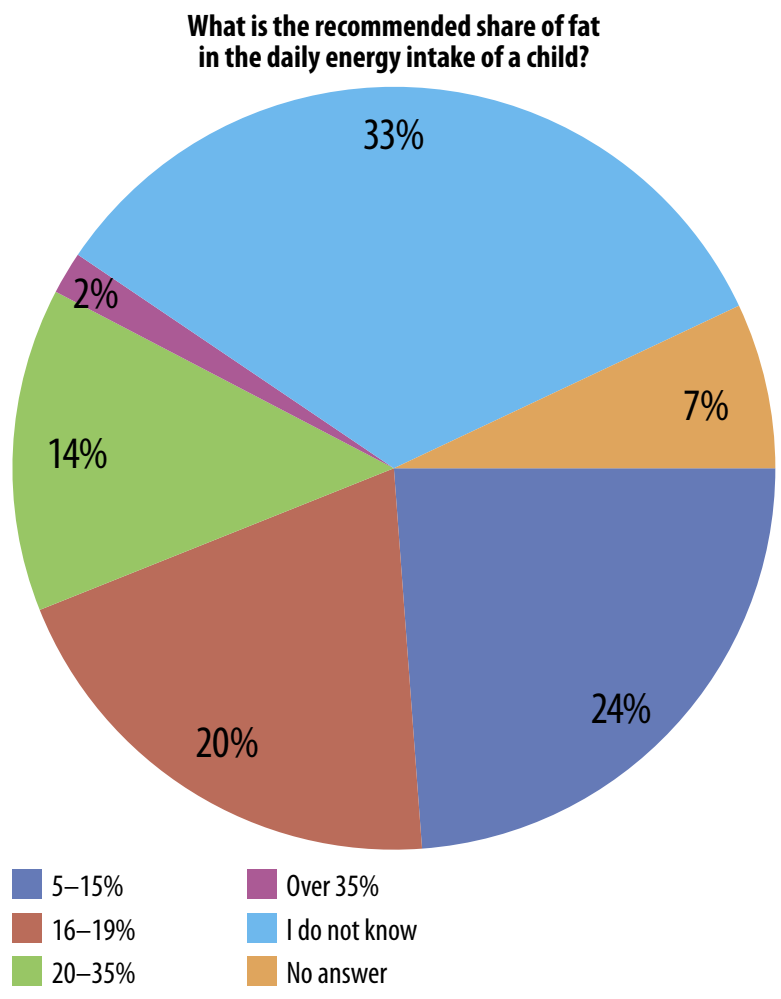

Fig. 5. Percentages of individuals providing a given answer to the question: "What is the recommended share of fat in the daily energy intake of a child?"

\section{What is the minimum recommended share of protein in the daily energy intake of a child?}

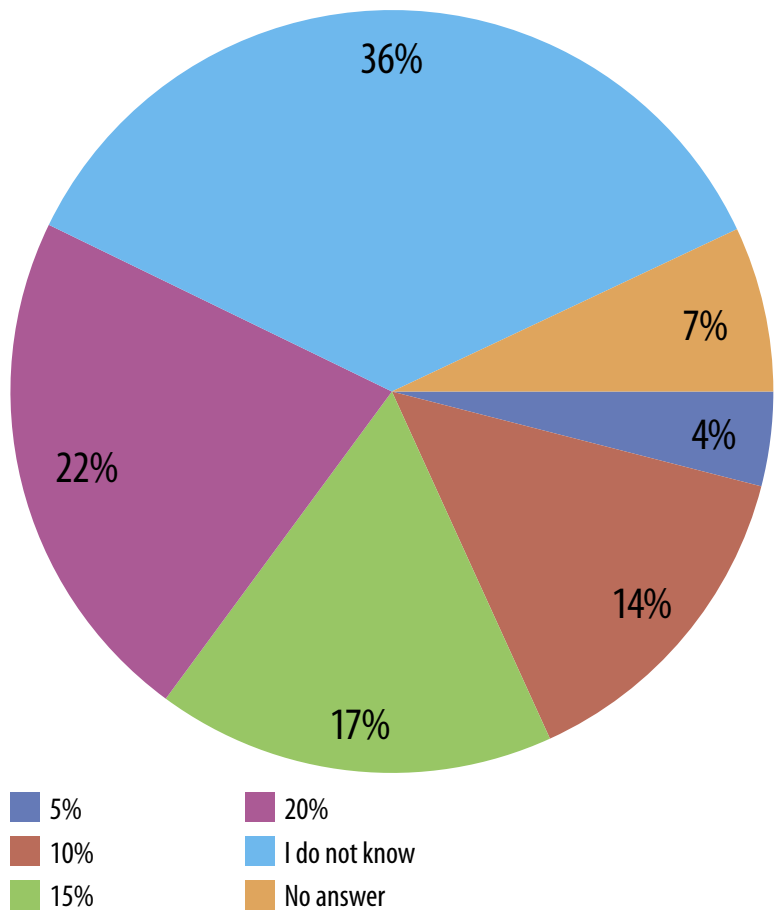

Fig. 6. Percentages of individuals providing a given answer to the question: "What is the minimum recommended share of protein in the daily energy intake of a child?" 


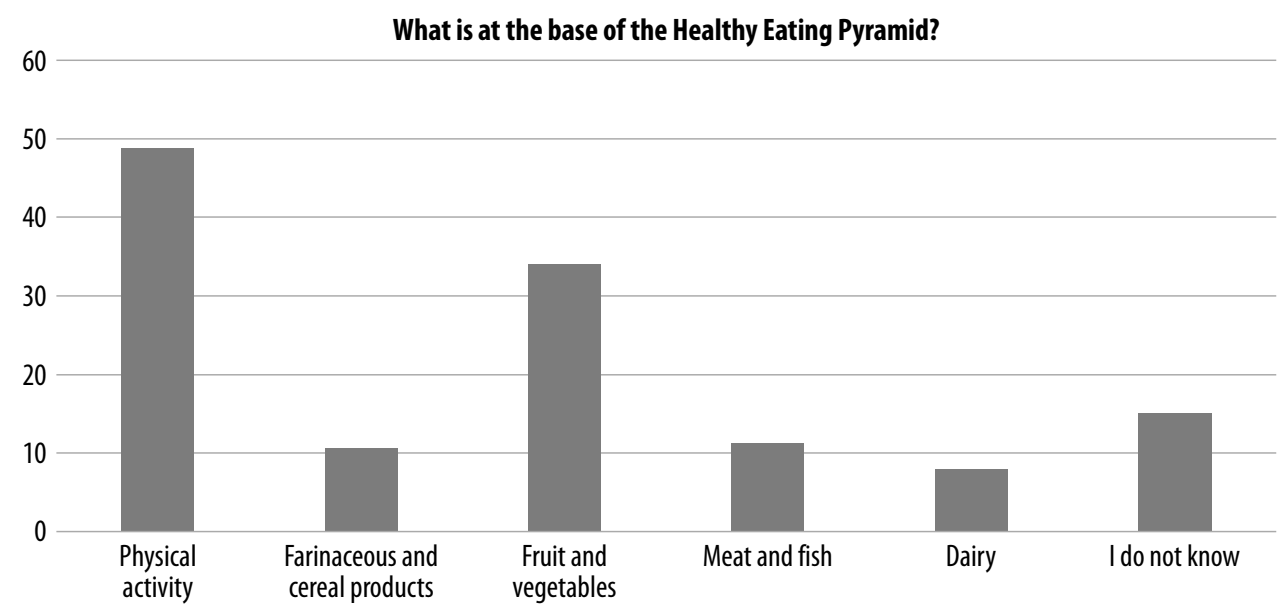

Fig. 7. Percentages of answers provided to the question: "What is at the base of the Healthy Eating Pyramid?" (more than one answer could be selected)

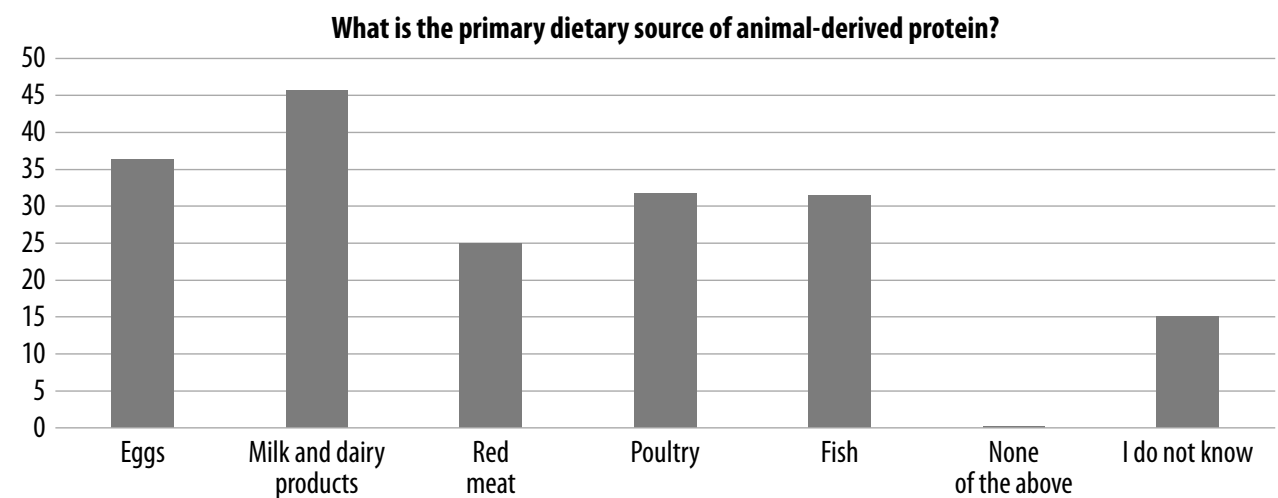

Fig. 8. Percentages of answers provided to the question: "What is the primary dietary source of animal-derived protein?" (more than one answer could be selected)

carbohydrates (50-70\% of energy demand) was provided by only $13.1 \%$ of parents, for fat (20-35\% of the demand), the figure was $13.7 \%$ and in the case of protein $(15 \%$ of the demand), $17 \%$ of the surveyed parents selected the correct answer.

The next question focused on the Healthy Eating Pyramid. Among the subjects, $48.8 \%$ were of the opinion that physical activity is at the base of the Pyramid. Fruit and vegetables were believed to be at the base of the Pyramid by $34.1 \%$ of the surveyed parents. The products that were least commonly considered to be at the base of the Healthy Eating Pyramid were meat and fish (11.3\% of the subjects), farinaceous and cereal products (10.6\%) and dairy (7.9\%). No knowledge on the subject was declared by $15.1 \%$ of parents. The results are presented in Fig. 7.

The main dietary sources of animal-derived protein most commonly indicated by the respondents included milk and dairy products (45.7\% of the subjects) and eggs (36.4\%). Poultry (31.7\%) and fish (31.5\%) were slightly less frequently selected. One in four respondents $(25.0 \%)$ believed red meat to be the primary source of animal-derived protein. The data are illustrated in Fig. 8.

Subsequently, the parents were asked to indicate which products have a large cholesterol content (over $200 \mathrm{mg}$ ). Parents most commonly selected cultured butter $(28.0 \%)$, chicken egg yolk (23.3\%) and baked pâté (21.3\%). Whole chicken eggs (14.9\%), ham (14.5\%), pork liver (12.7\%) and pork brain $(10.5 \%)$ were less frequently selected options. As many as $38.9 \%$ of the subjects admitted to having no knowledge of the cholesterol content in the products mentioned above (Fig. 9). Further questions concerned parental knowledge on the amount of energy supplied to the body with selected nutrients. The results are presented in Fig. 10-14. What is alarming is the fact that over half of the surveyed parents admitted that they did not know how many kilocalories are supplied to the body with 1 gram of fat, carbohydrates, protein, ethyl alcohol and fibre. The correct calorific value of fat (9 kcal) was indicated by only $12.8 \%$ of the subjects, of protein ( $4 \mathrm{kcal}): 13.7 \%$, of carbohydrates ( $4 \mathrm{kcal}): 9 \%$, of alcohol (7 kcal): $7.6 \%$, while the calorific value of fibre $(2 \mathrm{kcal})$ was known only by $12.3 \%$ of parents.

The survey also asked about the minimum recommended time for moderate physical activity of a child (going for a walk, dancing, riding a bike, swimming). There were $43.4 \%$ of the respondents who were right to think that a child should have a minimum of 30-60 minutes of moderate physical activity daily. Among the subjects, $21.3 \%$ stated that physical activity should take more than an hour a day, while $11.7 \%$ selected 15 minutes as the time for daily 


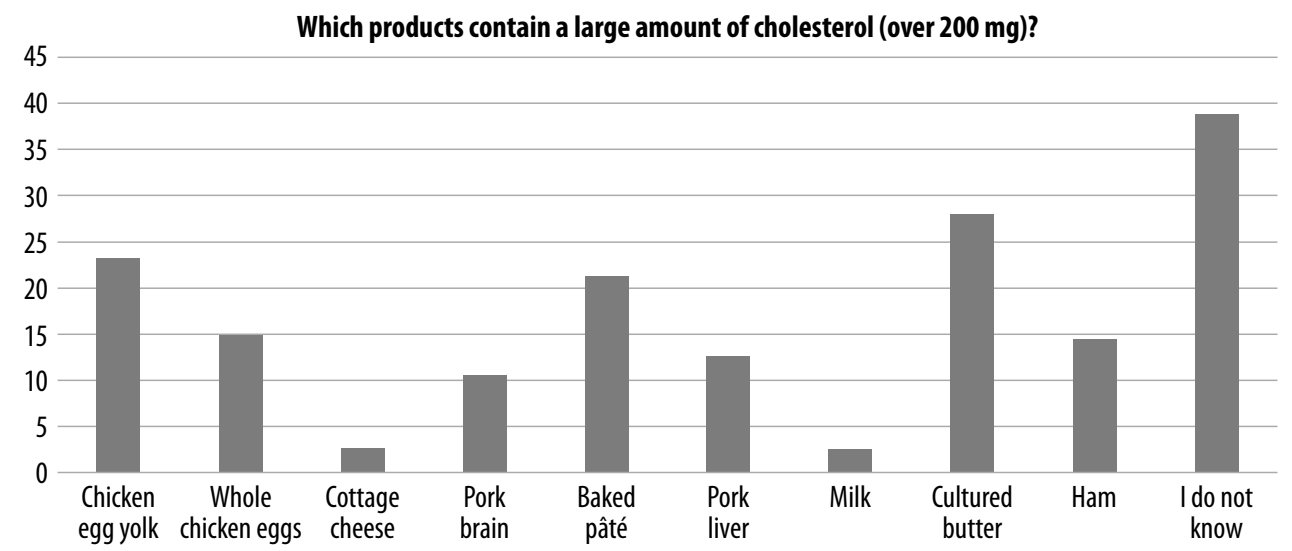

Fig. 9. Percentages of answers provided to the question: "Which products contain a large amount of cholesterol (over $200 \mathrm{mg}$ )?" (more than one answer could be selected)

\begin{tabular}{|l|c|c|}
\hline \multicolumn{1}{|c|}{ Answer selected } & $\boldsymbol{n}$ & $\%$ \\
\hline $\begin{array}{l}\text { Physical activity is not important for a normal development } \\
\text { of a child }\end{array}$ & 25 & 3.8 \\
\hline $\begin{array}{l}\text { The child should decide themselves how much physical } \\
\text { activity to have }\end{array}$ & 33 & 5.0 \\
\hline At least 15 minutes a day & 77 & 11.7 \\
\hline At least 30-60 minutes a day & 285 & 43.4 \\
\hline At least an hour a day & 140 & 21.3 \\
\hline I do not know & 53 & 8.1 \\
\hline No answer & 43 & 6.0 \\
\hline
\end{tabular}

Tab. 5. Numbers and percentages of individuals providing a given answer to the question: "What is the minimum time of moderate physical activity a child should have?"

\begin{tabular}{|c|c|c|}
\hline \multicolumn{2}{|c|}{ Correlation analysis } & Child's BMI \\
\hline \multirow{3}{*}{$\begin{array}{c}\text { Parental knowledge on child nutrition } \\
\text { guidelines }\end{array}$} & Pearson's $r$ & 0.01 \\
\cline { 2 - 3 } & Significance & 0.851 \\
\cline { 2 - 3 } & $n$ & 460 \\
\hline
\end{tabular}

Tab. 6. Correlations of a child's body mass index with parental knowledge of child nutrition guidelines

moderate physical activity of a child. The remaining parents believed that it is the child who should decide about the amount of physical activity (5.0\%) or that physical activity is not important for the normal development of a child (3.8\%). There were $8.1 \%$ of the respondents who admitted to not knowing the answer to the question, while $6.0 \%$ did not provide any answer at all. The results are presented in Tab. 5 .

\section{Analysis of correlation between parental knowledge and selected variables}

All answers provided to the questions above were analysed and parents' knowledge of healthy eating guidelines was assessed based on the number of correct answers (each correct answer was awarded 1 point). The maximum possible score was 15 points, while the mean score for the whole study group was $M=3.08 ; S D=2.18$. Subsequently, it was

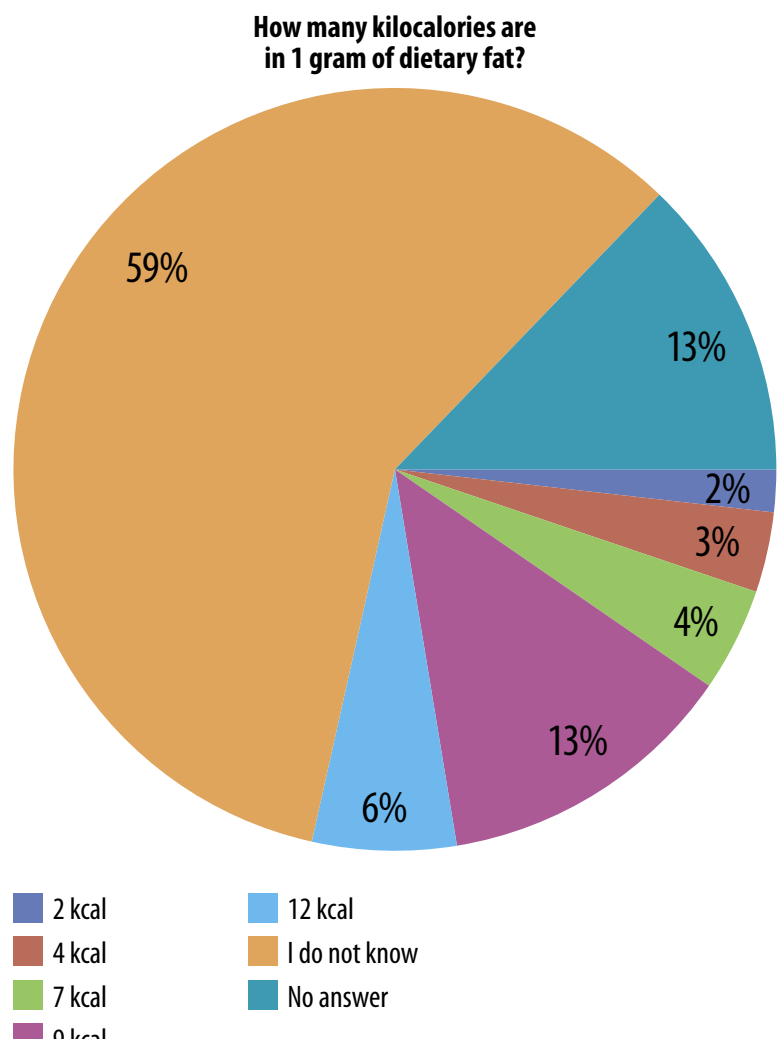

$9 \mathrm{kcal}$

Fig. 10. Percentages of individuals providing a given answer to the question: "How many kilocalories are in 1 gram of dietary fat?"

between a child's BMI and their parents' knowledge on nutrition. To this end, correlation analysis using Pearson's $r$ coefficient was performed. The results, which are presented in Tab. 6, show that there is no statistically significant correlation between a child's BMI and their parents' nutritional knowledge. Further analysis was performed to check whether parents' knowledge of healthy eating guidelines is dependent on their overweight/obesity and exercising together with their child. The Mann-Whitney $U$ test determined that overweight/obesity in a parent does not differentiate between levels of knowledge on healthy eating guidelines (Tab. 7). It was 


\begin{tabular}{|l|c|c|c|c|c|c|c|}
\cline { 2 - 7 } & \multicolumn{2}{c|}{$\begin{array}{c}\text { Parents with overweight/ } \\
\text { obesity }(\boldsymbol{n = 1 2 6 )}\end{array}$} & $\begin{array}{c}\text { Parents without overweight/ } \\
\text { obesity }(\boldsymbol{n = 4 5 4})\end{array}$ & \multicolumn{3}{c|}{ Results of statistical analysis } \\
\cline { 2 - 8 } & $\boldsymbol{M}$ & SD & $\boldsymbol{M}$ & SD & $\boldsymbol{Z}$ & $\boldsymbol{p}$ & $\boldsymbol{r}$ \\
\hline Level of knowledge on nutrition guidelines & 3.28 & 2.43 & 3.05 & 2.12 & -0.72 & 0.471 & 0.02 \\
\hline
\end{tabular}

Tab. 7. Means, standard deviations and significance of differences in the level of parents' knowledge on nutrition guidelines depending on their overweight/obesity

\begin{tabular}{|c|c|c|c|c|c|c|c|}
\hline & \multicolumn{2}{|c|}{$\begin{array}{l}\text { Parents who exercise with } \\
\text { their children } \\
(\mathbf{n}=188)\end{array}$} & \multicolumn{2}{|c|}{$\begin{array}{l}\text { Parents who do not exercise } \\
\text { with their children } \\
(n=318)\end{array}$} & \multicolumn{3}{|c|}{ Results of statistical analysis } \\
\hline & $M$ & SD & $M$ & SD & $Z$ & $p$ & $r$ \\
\hline Level of knowledge on nutrition guidelines & 3.22 & 2.21 & 3.02 & 2.16 & -1.07 & 0.283 & 0.03 \\
\hline
\end{tabular}

Tab. 8. Means, standard deviations and significance of differences in the level of parental knowledge on nutrition guidelines depending on parents exercising with their children

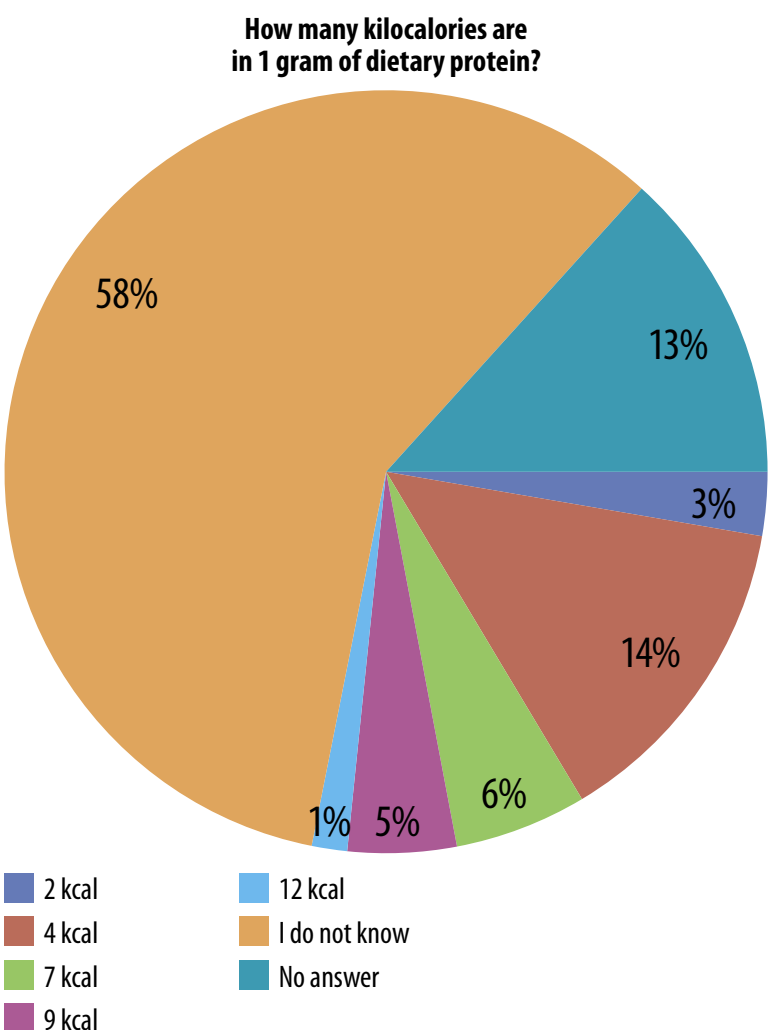

Fig. 11. Percentages of individuals providing a given answer to the question: "How many kilocalories are in 1 gram of dietary protein?”

\begin{tabular}{|c|c|c|}
\hline \multicolumn{2}{|c|}{ Correlation analysis } & $\begin{array}{c}\text { Level of parental knowledge } \\
\text { on nutrition guidelines }\end{array}$ \\
\hline \multirow{4}{*}{ Maternal education } & Spearman's rho & 0.20 \\
\cline { 2 - 3 } & Significance & $<0.001$ \\
\cline { 2 - 3 } Wykształcenie ojca & $n$ & 492 \\
\hline & Spearman's rho & 0.13 \\
\cline { 2 - 3 } & Significance & 0.004 \\
\cline { 2 - 3 } & $n$ & 483 \\
\hline
\end{tabular}

Tab. 9. Correlations of parents' knowledge on nutrition guidelines with their education

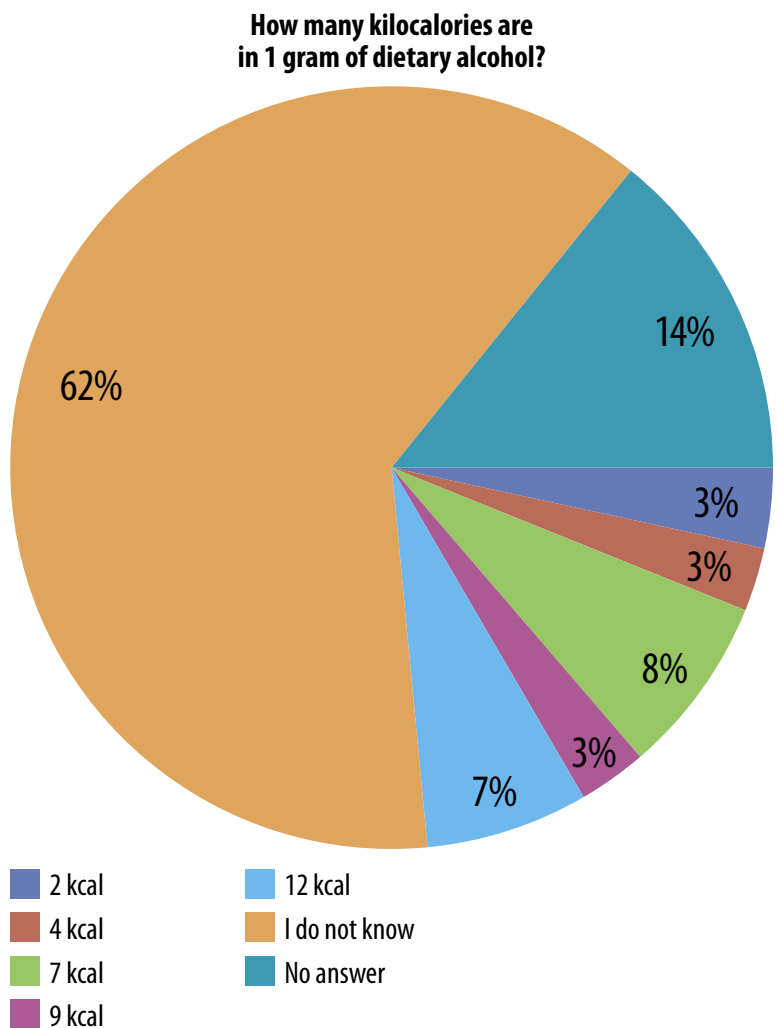

Fig. 12. Percentages of individuals providing a given answer to the question: "How many kilocalories are in 1 gram of dietary alcohol?"

also analysed whether there is a statistically significant difference between parents who exercise together with their children and those who do not in terms of their level of knowledge on healthy eating guidelines. The Mann-Whitney $U$ test was also used to calculate that. According to the data included in Tab. 8, exercising together with children or not does not differentiate between the respondents' levels of knowledge. Finally, a link between the level of education and nutritional knowledge was investigated. Correlation analysis using Spearman's rho shows that both maternal and paternal education is associated with the level of nutritional knowledge. The strength of these relationships is very weak, but 


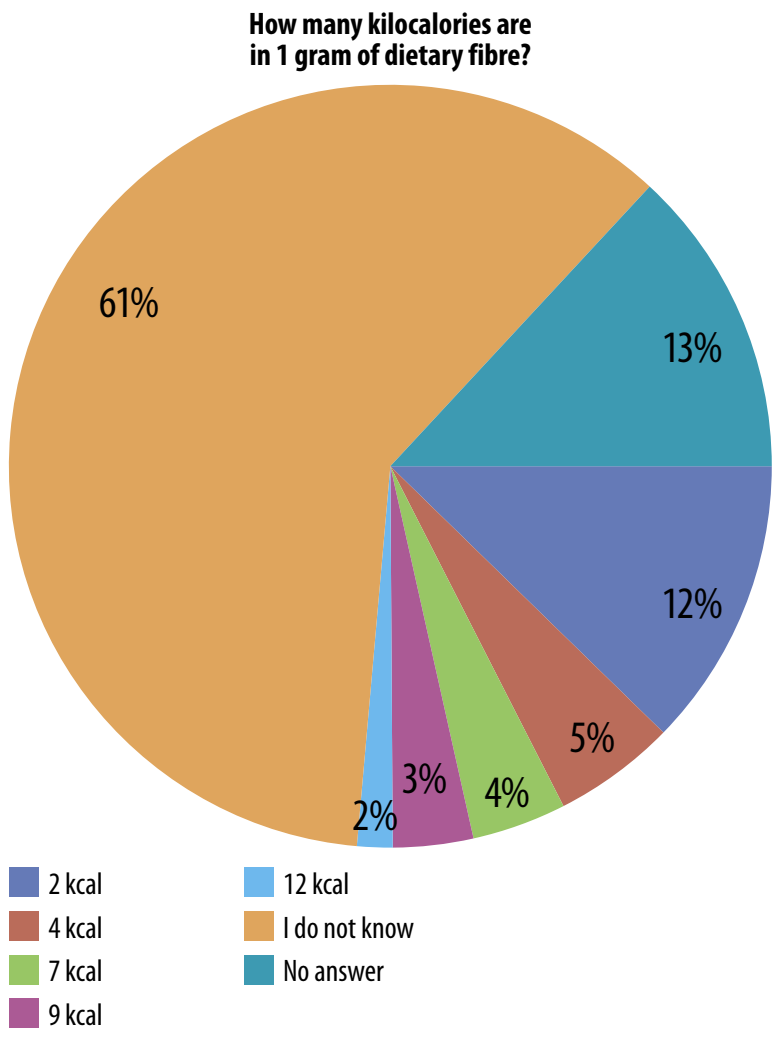

Fig. 13. Percentages of individuals providing a given answer to the question: "How many kilocalories are in 1 gram of dietary fibre?"

their direction is positive (Tab. 9). Thus, it can be concluded that the higher the level of education, the more substantial parental knowledge on nutrition is. No significant difference was found between the strength of correlation of maternal education with knowledge on nutrition and the strength of correlation of paternal education with knowledge on nutrition $(z=1.12 ; p>0.05)$.

\section{DISCUSSION}

In the currently available literature, research papers on parental knowledge of dietary recommendations for schoolchildren are scarce. There are far more studies on the knowledge of children and adolescents themselves, and of the parents of newborns or infants. This study quotes the research results that could be compared to the ones obtained by the present authors. In their survey study, Wyka et al. asked parents to rate their level of knowledge on healthy eating. It turned out that more than $62 \%$ of the surveyed parents evaluated their nutritional knowledge as good. Approximately $74 \%$ of the respondents answered that a child should eat five meals a day, $17 \%$ indicated four meals and $9 \%$ three meals a day. A question regarding the right amount of water that a child should drink was answered correctly by only $5.14 \%$ of the respondents. The highest proportion of sub-

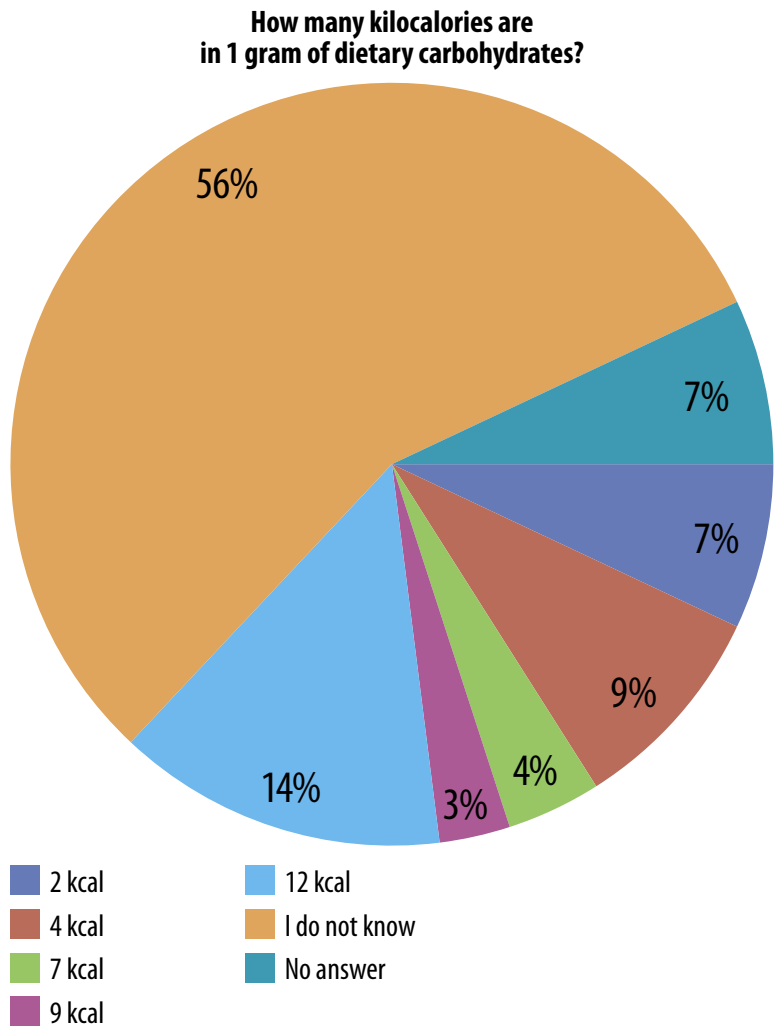

Fig. 14. Percentages of individuals providing a given answer to the question: "How many kilocalories are in 1 gram of dietary carbohydrates?"

In a study conducted in the United States of America, Etelson et al. asked parents about the recommended consumption of fruit juice and fast food by children. They demonstrated that the majority of parents are aware of the healthy choices regarding these types of food and drink. Two in three respondents stated that children should drink no more than $500 \mathrm{~mL}$ of fruit juice a day, while practically all parents indicated that meals from fast food outlets should be limited to one per week at most. The answers provided did not differ significantly between the parents whose children were overweight and other parents ${ }^{(10)}$. Merkiel and Chalcarz investigated the knowledge of parents of preschool children from the city of Nowy Sącz, Poland, and the surrounding areas. In their study, 96.7\% of the surveyed parents knew that proteins are the main building blocks of the human body, while more than $90 \%$ were aware of the fact that carbohydrates are the main source of energy ${ }^{(11)}$. Similar results were obtained in a study on the nutritional knowledge of parents from the city of Pabianice, Poland, and the surrounding areas ${ }^{(12)}$. Over $60 \%$ of parents knew the main guidelines for a balanced diet in terms of the content of basic nutrients. Unfortunately, similar to the present study, parents had a decisively poorer knowledge on the calorific value of basic nutrients ${ }^{(11)}$. In a study by Harton et al., only one in three parents knew the right amount of milk and dairy products to be consumed by children. Internet was the main source of 
knowledge on the subject $(63 \%)^{(13)}$. In a study by Cudzich, children and adolescents aged 6-18 years and their parents had an insufficient level of knowledge on healthy eating guidelines. It turned out that parents' knowledge on the subject had a significant effect on the presence of overweight and obesity in their offspring. However, neither parental education nor obesity had an effect on the presence of excessive body weight in children ${ }^{(14)}$. A study by Kozłowska-Wojciechowska et al. confirmed an interesting hypothesis that we can educate parents by educating their children. When informational programmes and brochures were implemented in primary schools and educational films for children were used, a distinct relationship was observed between the educational materials received by children and a change in certain dietary habits and an increase of knowledge in their parents. Thus, it turns out that educating children and adolescents can be treated as one of effective methods of educating their parents ${ }^{(15)}$.

\section{CONCLUSIONS}

Based on the results of the present study, one may conclude that the nutritional knowledge of parents of pupils aged 10-13 years attending primary schools in selected areas of the Silesian Province of Poland is insufficient. The surveyed parents did not demonstrate adequate knowledge on nutrition regarding both the recommended number of meals to be consumed by children during the day and the frequency of eating basic food products such as milk and dairy products, meat, fish, eggs, and fruit and vegetables. On average, one in three parents do not know what the recommended share of basic nutrients in the daily energy intake of a child is. More than half of the surveyed parents do not know the calorific value of fat, carbohydrates, protein, ethyl alcohol and fibre. There are only slightly more than $40 \%$ of the respondents who know that a child should have at least 30-60 minutes of moderate physical activity daily. It also turned out that the higher the level of education, the more substantial parental knowledge on nutrition is. A lack of awareness of nutrition guidelines in parents may result in the development of poor dietary habits and their consequences in their children. For this reason, it is very important to promote healthy lifestyle both among children and their parents, which is based on physical activity and adequate nutrition. The authors believe that it is necessary to implement educational programmes on food and dietary standards in primary schools addressed to both children and parents.

\section{Conflict of interest}

The authors do not report any financial or personal affiliations to persons or organisations that could adversely affect the content of or claim to have rights to this publication.

\section{References}

1. International Obesity Taskforce: Childhood report. IASO Newsletter 2004; 6: 10-11.

2. Abramowicz P, Konstantynowicz J, Piotrowska-Jastrzębska JD: Relationships between fat and bone during growth. Pediatr Med Rodz 2013; 9: 338-349.

3. Dziwisz S: Wdrażanie zasad zdrowego żywienia w szkołach publicznych. Kontrola Państwowa 2017; 5: 61-71.

4. Jung A: Obesity - a lifestyle disease. Pediatr Med Rodz 2014; 10 : 226-232.

5. Jonczyk P, Potempa M, Kajdaniuk D: Analiza stopnia odżywienia i zaburzeń odżywiania oraz charakterystyka przyzwyczajeń żywieniowych i aktywności fizycznej wśród dzieci w wieku 6-13 lat uczęszczających do wybranych szkół podstawowych na terenach wiejskich województw śląskiego i opolskiego. Pediatr Med Rodz 2016; 12: 177-193.

6. Kryska S, Grajek M, Sobczyk K: Czynniki rodzinne wpływające na kształtowanie nawyków żywieniowych dzieci. Piel Pol 2015; 56: 212-215.

7. Białokoz-Kalinowska I, Konstantynowicz J, Abramowicz P et al.: Uwarunkowania środowiskowe a nawyki żywieniowe młodzieży z regionu Podlasia. Pediatr Współcz Gastroenterol Hepatol Żywienie Dziecka 2006; 8: 117-120.

8. Kułaga Z, Litwin M, Grajda A et al.; Grupa Badaczy OLAF: Rozkłady wartości ciśnienia krwi w populacji referencyjnej dzieci i młodzieży w wieku szkolnym. Stand Med 2010; 7: 853-864.

9. Wyka J, Grochowska-Niedworok E, Malczyk E et al.: Wiedza żywieniowa rodziców oraz występowanie nadwagi i otyłości wśród dzieci w wieku szkolnym. Bromat Chem Toksykol 2012; 45: 680-684.

10. Etelson D, Brand DA, Patrick PA et al.: Childhood obesity: do parents recognize this health risk? Obes Res 2003; 11: 1362-1368.

11. Merkiel S, Chalcarz W: Wiedza żywieniowa rodziców dzieci przedszkolnych z Nowego Sącza i okolic. 1. Wiedza ogólna o żywieniu dzieci. Zywienie Czlow Metabol 2009; 36: 385-389.

12. Chalcarz W, Hodyr Z: Wiedza żywieniowa rodziców dzieci $\mathrm{w}$ wieku przedszkolnym. Materiały X Jubileuszowej Międzynarodowej Konferencji Naukowej: Uwarunkowania środowiskowe zdrowia dzieci. Legnica, 1-2 czerwca 2001: 117-121.

13. Harton A, Giżyńska A, Myszkowska-Ryciak J: Wiedza żywieniowa rodziców a spożycie mleka i produktów mlecznych przez dzieci w wieku przedszkolnym. Handel Wewnętrzny 2018; 4: 121-135.

14. Cudzich K: Znajomość zasad zdrowego żywienia oraz nawyki żywieniowe dzieci i młodzieży z otyłością i ich rodziców. Praca magisterska. Uniwersytet Jagielloński, Wydział Lekarski, Kraków 2014.

15. Kozłowska-Wojciechowska M, Uramowska-Żyto B, Jarosz A et al.: Wpływ edukacji żywieniowej dzieci w wieku szkolnym na wiedzę i zachowania żywieniowe ich rodziców. Rocz Panstw Zakl Hig 2002; 53: 253-258. 